\title{
An International Exploration of Decline
}

Daniel C. Levy

Daniel C. Levy is a Distinguished Professor at the University at Albany, State University of New York, and is director of the Program for Research on Private Higher Education. E-mail dlevy@uamail.albany.edu.

Growth has rightly formed a dominant theme in the study of private higher education, and expansion continues mostly unabated. However, the decline of private higher education constitutes an untold reality, and growth is not a uniform, omnipresent, or inevitable course. History even records private higher education abolition. Less radically, various types of private higher education declines occur even while private numbers usually grow-a more common phenomenon on the public side in recent decades.

Reasons for private higher education decline can be categorized in two broad categories-(1) social and (2) political or public-sector policies.

\section{Social Factors}

The decline of private higher education is seriously caused by the lapse of social identity and distinctiveness that previously fueled private growth. The weakening of Catholic identity in the Americas is a prominent case in point. The distinctive Catholic orientation has become less defining even at private institutions that remain officially Catholic. Fewer families chose private education on religious grounds. Similarly, as mainstream society becomes more open mainstream to young women, fewer families chose private education on gender grounds. 
A different socially based decline is demographically induced, as a population shift comes to affect overall demand for higher education. The demographic shift could, most dramatically, produce in higher education an actual fall or at least a reversal of strong growth. Such a basis of private higher education decrease is not common in the developing world, while there are cases (see the article on Thailand in this special section) and it is a powerful factor in the developed world. Demographic decline has not affected western European private higher education much, since private higher education is still a small sector in most countries. Yet, in Portugal, the country with the largest private higher education sector, that share fell from 36 to 25 percent, from 1996 to 2006. Some programs no longer attract applicants, and some private higher education institutions have faced deaths or at least mergers. Eastern Europe has much higher shares of private higher education, and thus the sector is more vulnerable to demographic decline. From 1996 to 2006, Georgian private higher education fell from 34 to 22 percent of enrollment. Russian private higher education may in the next few years suffer from the national demographic crisis.

With the Republic of Korea following suit, Japan already shows the sharpest effects of demographic stagnation as a rare case of private higher education decline in absolute numbers, though the public sector has seen similar losses. Within the private sector, the lower-status nonuniversities have suffered the most, though the sector has also shown entrepreneurial skill in adding nontraditional student populations. Still, the near future could witness difficulty for the Japanese private sector, including institutional closings and mergers. 
Politics and the Impact of the Public Sector

On the political side, public policy can strongly impact private higher education. Many policies or postures promote growth, but others have undermined growth; among the latter are the following four.

Hostile government. At the extreme, government has banned private higher education. In much of the world, private higher education was banned before it ever emerged. But communism (in eastern Europe and China) has been the most significant example about decline. Other left-leaning governments have abolished private higher education (Pakistan and Turkey), though such bans have generally been short-lived. Much less dramatically, left-leaning democratic governments have sharply boosted public-sector growth. Argentina's 1983 redemocratization brought sudden open admissions at the national public university, and the private higher education sector dropped from 22 to 13 percent by 1985. Today, some governments have come to power on broad anti-privatization platforms.

Regulation. In other situations, without a modification of government administration, public-policy change brings a decline in private higher education. Government sometimes moves to increased regulation of private higher education. This is striking as "delayed regulation" after an initial private higher education period of rather laissez-faire proliferation. Such an evolution has been visible in much of eastern Europe, Africa, and Latin America. Licensing standards emerge or expand, accreditation is introduced, and laws are promulgated. Sometimes regulation of matters such as program offerings exceeds options faced by public universities, with their relative autonomy, own statutes, venerable legitimacy, and political power. Examples have included Thailand, Japan, Argentina, and Brazil. Rules (e.g., in accreditation) imposed on private higher education are really more suitable to the public sector. Often, public 
universities lobby powerfully for more restrictions on private higher education. Government-set tuition caps can be onerous for private higher education size.

Public higher education expansion. As noted, historically, periods of sharp public expansion have occurred, which, in turn, decrease the private higher education sector's share. This is what happened, for example, with the huge postwar development of US two-year public community colleges. Both Colombia and Thailand show the effects of rapid public expansion on the private higher education sector, as the respective articles in this special section show. Enrollment grows in existing public institutions, new institutions are created, and existing institutions are elevated to higher education status.

Privatization within the public sector. Public higher education-like other challenged public enterprises-can partly privatize. The paradox is captivating: public institutions protect themselves against private ones by privatizing themselves. Of course, the selfprivatization is only partial; public universities almost never become private ones. Or it is less a matter of public university desire than necessity, due to the competition from private institutions or to government pushing their hands. Measures include "private" management methods, more market responsiveness, increasing in contracting, and so forth. Given the continuing public advantages of low or no tuition and often of traditional status, a degree of such privatization can be an effective bump against private higher education.

Perhaps the most dramatic (and threatening) public partial privatization is the opening of second "modules." Tuition charging and market oriented, these programs allow public universities to take in more students than otherwise and in other ways compete right on the private universities' turf. Kenya is a strong example, where the private share has fallen from around 20 to 10 percent. In Georgia, the proportion of selffinanced students within public universities rose to 43 percent by 2002, and private 
higher education's share of total higher education diminished. Several Asian public universities now also have module II programs.

\section{Conclusion}

Many types of private higher education do decline and for various reasons. Yet, private higher education grows significantly despite all the negative factors identified. The overall private higher education decrease almost always refers to public- and privatesector shares, not absolute enrollment. Even proportional decline in the private sector applies only to a minority of countries. The most vulnerable private higher education is the demand-absorbing type, which underscores that all parts of the sector do not face constant vulnerability. Moreover, private higher education institutions are not inevitably hapless sufferers; evidence of new initiatives includes reaching out (including internationally) to new kinds of students, in new modalities.

Similarly, between the private and public sectors, some factors may bring about private higher education decline alongside factors that create private higher education growth. In sum, even though growth remains the major trend for private higher education, the decline of private higher education warrants analysis for contemporary dynamics as well as historical and future ones. The major and traditional question of how society divides its activities into private and public sectors is today overwhelmingly answered in higher education as a shift to the private, but it is neither a uniform nor unrelenting shift. 